\title{
ORIENTASI KEAGAMAAN MASYARAKAT STUDY KASUS KOMUNITAS KRISTEN ROTE DAN SABU KOTA ADMINISTRASI KUPANG
}

\author{
Oleh : H. A. Shadiq Kawu
}

\section{A. Latar Belakang dan Masalah}

Pembangunan bidang agama, sebagaimana dirumuskan dalam GBHN diarahkan kepada penataan kehidupan beragama dan kepercayaan terhadap Tuhan Yang Maha Esa yang tercermin dalam kehidupan sehari-hari dengan semakin meningkatnya keimanan, pengamalan agama, dan makin meningkatnya kerukunan kehidupan umat beragama, baik antar umat beragama maupun intern umat beragama. Hal ini dapat diartikan bahwa pembangunan bidang agama masih bertumpu pada upaya penciptaan tiga kondisi ideal, yaitu : kadar keimanan dan ketakwaan yang tinggi; wawasan keberagamaan yang luas, matang dan berkembang; dan kerukunan keberagamaan yang mantap dan dinamis menyukseskan keberagamaan yang mantap dan dinamis untuk menyukseskan pembangunan nasional.

Penelitian yang diadakan Badan Litbang Agama, tahun 1988/1989 pada berbagai tipe komunitas sosial telah ditemukan bahwa proses modernisasi belum sanggup menggeser citra manusia ideal, yaitu manusia yang selalu taat pada ajar an agama. Ini sejalan dengan temuan lainnya yang menyebutkan bahwa tujuan kehidupan manusia adalah untuk mengabdi kepada tuhan dan bersyukur kepada Tuhan apabila mendapatkan kebahagiaan. Dengan kata lain, temuan-temuan itu menunjukkan bahwa orientasi kepada Tuhan sangat kuat dalam masyarakat yang diteliti. Namun demikian, penelitianpenelitian yang pernah dilakukan belum spesifik mengungkapkan corak orientasi keagamaan masyarakat. Khususnya bila berkaitan dengan komunitas dan etnis tertentu, bahkan memiliki corak khas dikaitkan dengan orientasi keagamaannya. Selain ityu diasumsikan pula, bahwa perubahan-perubahan yang terjadi sebagai akibat akulturasi budaya lokal dengan budaya asing lewat jalur komunikasi dan transfortasi sebagai hasil pembangunan selama 25 tahun terakhir telah menimbulkan konfigurasi perubahan yang berbedabeda pula dalam hal orietasi keagamaan komunitas etnis.

Berdasar asumsi tersebut, penelitian diadakan, yakni untuk mengetahui bagaimana orientasi keagamaan masyarakat pada komunitas Kristen Rote dan Sabu di Propinsi Nusa Tenggara Timur.

\section{B. Masalah Penelitian}

Masalah pokok penelitian ini, adalah bagaimana corak orientasi keagamaan komunitas Rote dan Sabu, khususnya yang tinggal di Kota Administrasi Kupang. Dari permasalahan tersebut, secara spesifik, dirumuskan beberapa pertanyaan penelitian, yaitu :

1. Apakah ada perubahan orientasi keagamaan pada komunitas etnis Kristen Rote dan Sabu, di Nusa Tenggara Timur.

2. Kalau terjadi perubahan orientasi keagamaan, ke arah manakah kecenderungan orientasi tersebut. 


\section{ORIENTASI KEAGAMAAN MASYARAKATA STUDI KASUS KOMUNITAS KRISTEN ROTE DAN SABU KOTA ADMINISTRATE KUPANG}

\section{Kerangka Teoritis}

Secara sederhana, orientasi keagamaan dapat diartikan sebagai pandangan tentang sesuatu yang dianggap penting sekali dalam kehidupan yang diatur serta dipengaruhi oleh pandangan budaya masyarakat setempat. Selain itu pengunaan orientasi keagamaan yang sama dengan orientasi nilai budaya didasarkan pada kenyataan bahwa nilai budaya terhadap suatu masalah dasar dalam hidup tidak bersifat mutlak dan kasku, tetapi berubah-ubah menurut keadaan lingkungan atau bidang kehidupan. Menurut Kluckhohn, orientasi terdiri atas empat bidang kehidupan, yaitu (1) kekeluargaan, (2) ekonomi, (3) sosial, (4) keagamaan (Koetjaraningrat, 1985). Dalam hal ini, orientasi nilai budaya terhadap lima masalah dasar tersebut akan dilihat dalam konteks lingkungan kehidupan keagamaan.

Selanjutnya, orientasi keagamaan tersebut akan dilihat dengan menggunakan yang dibuat oleh Lenski (1961). Lenski membagi pandangan keagamaan menjadi tujuh macam orientasi. Namun dalam penelitian ini dibatasi hanya 4 orientasi, yaitu :

1. Mistisisme, yaitu paham yang menekankan pentingnya oleh batin dalam mencapai Tuhan dan pencarian spiritual atas kebenaran dan hikmah tersembunyi, biasanya malalui tahapantahapan penyucian diri, pemurnian tawassul jiwa, pencerahan dan penyatuan dengan Tuhan. Tawassul merupakan aspek penting, khsussnya bagi mereka yang belum terbiasa dengan proses penyucian diri terus menerus (muslim awam), sementara zauq (rasa mengalami langsung) merupakan situasi jiwa yang selalu didambakan.
2. Seremonialisme, yaitu orientasi keagamaan yang meandang bahwa upacara ritus itu merupakan inti ajaran agama dan inti kebenaran. Yang paling dipentingkan adalah penyelenggaraan upacara dan tidak terlau menghiraukan substansi dari upacara itu sendiri. Keberagamaan seseorang diukur dari aktivitas keupacaraannya.

3. Ortodoksi, yaitu orientasi keagamaan yang menekankan betapa epentingnya pelaksanaan ajaran agama yang murni dan tidak bercampur dengan ajaranajaran lain (heterodoks). Keberagamaan diukur pada ketepatan pemahaman sebagaimana tersurat dalam teks (skriptualistik) dan pengalaman terhadap praktek-praktek upacara/ritus keagamaan yang tidak bersumber dari teks.

4. Etikalisme, yaitu orientasi keagamaan yang menekankan pentingnya upaya pemeluk agama untuk memajukan kesejahteraan umat manusia. Kebenaran agama diukur dari sumbangsi seseorang kepada pembangunan nilainiiai moral/kesusilaaan dan kepantasan uamat manusia. Substansi agama, dengan demikian lebih penting dibanding kulitnya.

\section{Metode Penelitian}

\section{Sasaran Penelitian}

Penetpan kelompok etnik Rote dan Sabu di Propinsi NUsa Tenggara Timur sebagai sasaran penelitian berdasarkan "hipotesa kelompok dominan" yang dikembangkan oleh Prof. Bruner. menurut Bruner (dalam Suparlan, 1993) unsur-unsur yang mencakup dalam hipotesa kebudayaan dominan adalah (1) secara demografi sosial atau ratio populasi terdapat adanaya mayoritas, (2) kebudayaan 
ORDBNTASIKEAGAMAAN MASYARAKATA STUDI KASUS KOMUNITAS KRISTEN ROTE DAN SABU KOTA ADMINISTRATIF KUPANG

lokal atau setempat yabng mantap dan berlaku dalam kota tersebut, (3) adanya suatu keistimewaan bagi suatu kelompok etnik yang mayoritas dalam pemerintahan.

Dengan acuan tersebut, sasaran penelitian ini ditetapkan di wilayah kota Administatif Kupang, dengan perincian, dua kelurahan khusus komunitas etnik Rote di Kecamatan Kupang Selatan, dan dua kelurahan di Kecamatan Kupang Utara, tempat komunitas etnik Sabu sebagai pusat konsentrasi pemukiman.

Dipilihnya dua etnis tersebut (Rote dan Sabu), sebgai sasaran dalam penelitian ini, selain karena kedua kelompok ini, termasuk penganut agama Kristen yang taat, juga etnis Rote dan Sabu, merupakan kelompok dominan yang mendiami daerah Kota Administrasi Kupang.

Daerah yang menjadi pusat konsentrasi etnis Rote dan Sabu di Kota Kupang, dan sekaligus menjadi lokasi penelitian ini, berbasis di Kelurahan Kuanino dan Oetee (Rote) dan Kelurahan Nunhila dan Nun Baun Sabu (etnis Sabu). Keempat kelurahan ini, terletak di pusat kota Administrasi Kupang.

\section{Sampling}

Secara domografis, persebaran penduduk di empat kelurahan sebagai sasaran penelitian sangat bervariasi. Ini disebabkan karena adanya perbedaan yang menjolok tentang jumlah penduduk (atau Kepala Keluarga) pada setiap lokasi penelitian. Karena itu penarikan sampel dengan dua cara, yang bertolak dari unit keluarga sebagai satuan sampel (Kanino dan Oeteta) dan ada yang berdasarkan prosentase dari jumlah populasi (Nunhila dan Nun Baun Sabu).

Jumlah sampel secara keseluruhan di empat lokasi penelitian, 260 orang, 70 orang di Kelurahan Kuanino, 90 orang di Kelurahan Oetete, dan 50 orang di Kelurahan Nun Baun Delha, dan 50 orang di Desa Nun Baun Sabu.

Penarikan sampel di Kuanino, diambil berdasarkan unit keluarga sebagai satuan sampel. Dari 11.885 jiwa penduduk di Kuanino, tercakup dalam 1223 Kepala Keluarga. Sekitar 60 persen atau sekitar 700 Kepala Keluarga dari populasi tersebut adalah orang Rote. Mereka memiliki konsentrasi-konsentrasi pemukiman pada 6 RW dari 10 RW yang ada di kelurahan tersebut. Dari 700 Kepala Keluarga orang Rote ditarik 10 persen sebagai sampel. Cara penarikan sampel dilakukan secara sistmatik dengan teknik random sampling, dengan memilih 12 kepala keluarga dari setiap RW konsentrasi etnik Rote.

Di Kelurahan Oetete, pemilihan responden dilakukan secara purposive dengan menentukan 2 RW ftukun Warga) yang dianggap dominan orang Rote. Dengan cara ini, kemudian ditetapkan RW II dan RW IV sebagai sasara penelitian dan penarikan responden. Kemudian dari kedua RW tersebut dipilih secara tidak sengaja 100 Kepala Keluarga sebagai sasaran pengedaran angket. Dari 100 angket yang diedarkan yang kembali hanya 95 eksamplar, namun setelah diseleksi hanya 90 eksamplar yang memenuhi syarat untuk diolah dan dianalisis. Oleh karena itu, penelitian di Kelurahan Oetete, khusus komunitas etnik Rote, responden yang ada sejumlah 90 orang.

Penarikan sampel di Kelurahan Nunhila dan Nun Baun Sabu berdasarkan populasi penduduk. Dalanm monografi tahun 1994, jumlah penduduk di Kelurahan Nunhila, sebanyak

No. 13 Th. VIII Juli/Desember 1996 


\section{OREENTASI KEAGAMAAN MASYARAKATA STUDI KASUS KOMUNITAS KRISTEN ROTE DAN SABU KOTA ADMINISTRATE KUPANG}

2013 orang, terdiri dari laki-laki 1062 orang dan wanita 951 orang. Jumlah Kepala Keluarga 361 jiwa. Darikeseluruhan jumlah populasi, sebanyak 1712 orang diantaranya memelurk agama Kristen Protestan, selebihnya Katholik 117 jiwa, dan Islam 184 jiwa. Penarikan sampel diambil secara puposive, berdasarkan jumlah pemeluk Kristen Protestan sebagai satuan populasi. Dari 1712 jiwa, penduduk yang beragama Kristen Protestan, terdapat sekitar seribu orang yang masuk kategor "usia dewasa". Dengan demikian penarikan sampel, ditetapkan lima puluh orang, yaitu lima persen dari jumlah penduduk Kristen dewasa.

Di Kelurahan Nun Baun Sabu, lebih dari 90 persen penduduk berasal dari etnik Sabu, yang memeluk agama Kristen Protestan. Populasi penduduk berdasarkan monografi Kelurahan, tahun 1994, tercatat 1876 jiwa. Dari jumlah populasi, sekitar 200 orang, diantaranya berasal dari etnik lain, seperti Timor, Buton, dan Rote.

Penarikan sampel, ditetapkan 50 orang dari jumlah penduduk asli Pula Sabu yang berusia dewasa. Dari 50 orang responden, 27 orang laki-laki dewasa dan 13 perempuan dewasa.

\section{Data dan Sumber Informasi}

Ada tiga jenis data (sifat, bahan, keterangan) yang dikumpulkan dalam penelitian ini, yaitu (1) riwayat, (2) frekensi dan distribusi, dan (3) tingkah laku tertutup/terselubung (covert behaviour). Ketiga corak atau jenis bahan keterangan tersebut berupa data primer, dan data sekunder.

Ketiga corak data (sifat bahan keterangan) tersebut dikumpulkan dengan menggunakan tiga teknik penumpulan data, yaitu (a) wawancara dan- penelusuran dokumen-dokumen tertulis, (b) pencacahan/angket, dan (c) observasi.
Data yang berkaitan dengan riwayat atau berkenan dengan etnografi diperoleh dari informasi dan sumbersumber tertulis. Informasi penting dalam penelitian ini adalah pemimpin masyarakat, terutama lurah dan stafnya. Pemimpin agama dan pemuka adat. Data yang bersifat pencacahan diperoleh dari sejumlah responden.

Data yang bersifat riwayat, dan etnografis dianalisis dengan menggunakan pendekatan kualitatif deskriptif, interpretatif. Penggunan metode kualitatif didasarkan pada pertimbangan untuk mengetahui secara lebih mendalam sasaran penelitian dan menyelami apa yang dialami para responden. Selanjutnya dengan metode kualitatif memunkinkan peneliti melakukan eksplorasi konsep-konsep yang boleh jadi akan hilang esensinya bila dilakukan dengan pendekatan lain (Bogran dan Taylor, 1975).

Data kuantitatif yang diperoleh dengan angket dianalisis dengan distribusi frekuensi, guna melihat kecenderungan-kecenderungan mengenai orientasi keagamaan masyarakat.

\section{Identitas Responden}

Sebagaimana telah dikemukakan, bahwa responden penelitian ini berjumlah 260 orang, terdiri dari 160 dari etnik Rote di Kecamatan Kupang Selatan, dan 100 orang etnis Sabu di Kecamatan Kupang Utara.

Secara keseluruhan, sekitar $74,44 \%$ responden adalah laki-laki. Hampir semuanya sebagai Kepala Rumah Tangga. Dilihat dari segi usia responden yang berusia antara 25-45 tahun, hampir berimbang dengan responden dewasa, yakni berusia di atas 45 tahun dengan posisi $50 \%$ dan $47,78 \%$.

Umumnya pendidikan responden dapat dikatakan sedang, bahkan ada kecenderungan agak tinggi, frekuensi 
ORIENTASI KEAGAMAAN MASYARAKATA STUDI KASUS KOMUNITAS KRISTEN ROTE DAN SABU KOTA ADMINISTRATE KUPANG

paling menonjol sekitar $40 \%$ adalah tamatan Sekolah Menengah Atas (SLTA). Kalau jumlah responden dikaiktkan dengan yang berpendidikan akademik atau Perguruan Tinggi $(16,67 \%)$ maka akan menjadi 56,67 $\%$, atau lebih besar dari yang berpendidikan SD dan SLTP yang hanya 43,33\%.

Apabila responden dilihat dari pencaharian, maka responden yang mempunyai penghasilan tetap tiap bulan, atau yang memperoleh jaminan hidup dari pemerintah, seperti pegawai negeri, ABRI dan pensiunan menduduki peringkat teratas $(56,67 \%)$. Hal ini tidaklah mengherankan, pada masyarakat di perkotaan, apalagi di pusat kota Propinsi. Sebagai pusat sentralisasi administrasi, sosialekonomi dan budaya di tingkat propinsi.

Yang menarik, karena responden yang mengaku pekerjaannya sebagai petani mencapai $14,44 \%$ cukup besar dibanding dengan mengaku sebagai buruh $(3,33 \%)$. Selain daripada itu, terdapat $4,44 \%$ responden yang belum mempunyai penghasilan tetapi, yaitu ibu rumah tangga yang hanya mengurusi keluarganya dan pelajar yang masih menuntut ilmu.

\section{IDENTIFIKASI WILAYAH PENELI- TIAN}

\section{A. Kondisi Geografis dan Struktur Pemerintahan}

Terdapat sebanyak 25 kelurahan dalam wilayah Kota Administratif $\mathrm{Ku}$ pang, ditambah 5 buah kelurahan persiapan. Sebanyak 12 diantara kelurahan defenitif masuk dalam wilayah Kecamatan Kupang Utara, dan selebihnya bagian dari Kecamatan Kupang Selatan.

Kelurahan Kuanino, dan Kelurahan
Oetete, yang merupakan basis pemukiman orang Rote di Kotif Kupang, masuk wilayah Kecamatan Kupang Selatan Kuanino, terletak di tengah-tengah wilayah kecamatan yang berbatan dengan Kelurahan Oebobo dan Oetete di sebelah utara. Kelurahan Fontein di bagian bara. Kelurahan Arimata di selatan dengan Kelurahan Naikoten 1 dan II di Timor.

Meski berada di kawasan pantai, sebagaimana Kotif Kupang pada umumnya, Kelurahan Kuanino berada pada ketinggi 300 meter di atas permukaan laut dengan tbpografi datar sampai tinggi. Permukaan tanahnya, umumnya ditutupi dengan batu karang hingga menyulitkan pemanfaatan lahan kosong dengan baik. suhu udaranya rata-rata sekitar 29 derajat celcius.

Luas wilayah Kuanino, 77.000 ha $\left(0,77 \mathrm{Km}^{2}\right)$ padat dengan bangunan dan fasilitas lain. Peruntukan lahan meliputi bangunan 76.950 ha, jalur hijau 1,8 ha, pertokoan 5 ha dan pasa desa 1 ha. Khusus sarana perekonomian terdapat 1 pasar, 105 toko, waning 23, kaki lima 30 dan 1 super maket, 2 buah hotel dan 6 restoran. Tempatnya yang strategis membuat Kuanino menjadi bagian dari pusat kegiatan ekonomi dan pemerintahan kota. Yang menonjol adalah banyaknya sarana trasportasi terdiri dari 120 mobil dinas, 162 buah mobil pribadi, 55 buah angkutan kkota, dan bus umum 11 buah. Di Kuanino, prasarana jalan mengambil porsi lahan 25 ha.

Seperti halnya, Kuanino, Kelurahan Oetete, masuk dalam wilayah Kecamatan Kupang Selatan. Daerah ini juga dominan dihuni orang Rote. Kelurahan Oetete, terletak di tengah Kota Kupang. Sebelah utara berbatasan dengan Kelurahan Kuanino. Sebagai bahagian dari daerah perkotaan, Oetete juga letaknya strategis terutama dari segi sarana perhubungan darat. Kelurahan ini, mudah dijangkau 


\section{ORIENTASI KEAGAMAAN MASYARAKATA STUDI KASUS KOMUNITAS KRISTEN ROTE DAN SABU KOTA ADMINISTRATE KUPANG}

dari segalah penjuru karena rata-rata dilalui trayek angkutan kota. Posisi strategis ini mempunyai dampak positif tersendiri bagi penduduknya, karena warga Oetete mempunyai mobilitas tinggi, dalam usaha perekonomian, juga dari sektor pendidikan.

Keadaan tanahnya terdiri dari batubatuan pembentuk tanah. Kegersangan tanah dapat diimbangi dengan usaha penduduk menanam pohon-pohon penghijauan, di samping usaha pemerintah sendiri menanam pohon pelindung di pinggir jalan. Halaman perumahan penduduk dan tanah-tanah kosong yang belum ditempati banyak ditanami berbagai macam pohon berjangka panjang, seperti pohon lontar dan pohon mangga.

Sepanjang jalan di pesisir pantai Laut Sawu yang membentang di pinggiran Kelurahan Nunhila dan Kelurahan Naun Baun Sabu, dua pemukiman dominan Sabu di Kecamatan Kupang Utara, ramai dengan hilir mudik kendaraan angkutan kota. Nunhila, bertetangga dengan Nun Baun Sabu. Kedua wilayah ini secara Spesifik mempunyai persamaan terutama dari segi lokasi pemukiman penduduk yang berada di daerah perbukitan, dengan batu-batuan yang membentuk tanah pemukiman penduduk.

Nunhila berbatasan dengan Nun Baun Sabu di sebelah barat, sebelah utara dengan laut Sawu, di arah selatan dengan Kelurahan Fatuveto dan arah timurnya juga berbatasan dengan Fatuveto. Pendudukan (mayoritas Sabut) membangun rumah tinggal di tanah yang miring ke bibir pantai Laut Sawu. Tanah yang miring tersebut digali sampai menjadi datar. Di atas tanah galian itulah, penduduk mendirikan rumah tinggal secara permanen. Di sela-sela bangunan perumahan tumbuh pohon lontar yang niranya dapat disadap dan diproduk jadi gula merah. Aral permukiman penduduk seluas 187 ha untuk saranajalan, 37 ha dan jalur hijau 12 kilometer.

Administrasi pemerintahan di Nunhila berbentuk kelurahan, terdiri dari $4 \mathrm{RW}$ dan 2 buah dusun.

Kelurahan Nun Baun Sabu berbatasan Kelurahan Nun Baun Delha Kecamatan Kupang Utara, selanjutnya berbatasan kelurahan Nomosain, di arah Timur dengan Kelurahan (Dese) Alak Kecamatan Kupang Barat, dan sebelah barat dengan pesisir pantai Laut Sawu.

Luas wilayah keseluruhan sekitar 61.441 hektar. Dibabnding dengan kelurahan lain yang ada di Kupang Utara, Nun Baun Sabu termasuk wilayah yang tingkat kepadatan penduduknya perkilometer ralatif rendah. Kelurahan ini dapat dijangkau dengan angkutan kota yang setiap harinya melewati satu-satunya jalur jalan propinsi yang melintang di kaki bukit berbatasan laut Sawu. Secara geografis, membentang di sepanjang pesisir pantai dengan pemukiman penduduk di atas bebukitan. Tanah pemukiman berasal dari jenis batu-batuan atau bahan keras dan bahan non volkanis. Oleh karena itu sektor pertanian dan perkebunan tidak dapat dikembangkan secara programatis dan intensif di wilayah ini. kecuali pohon-pohon lontar yang tumbuh subur di sela-sela perumahan penduduk, merupakan salah satu jenis pohon yang dapat tumbuh di daerah ini.

Pemandangan sepanjang haji, terutama di musim timur, antara April sampai Oktober, perkampungan penduduk diwarnai tiupan angin kencang dari arah laut Sawu, sementara hempasan omban yang keras kedengaran cukup jelas dari puncakpuncak bukit yang padat dengan rumah tinggal permanen. Disiang hari udara sangat panas, dari sebaliknya malam harinya terasa dingin. 
ORIENTASI KEAGAMAAN MASYARAKATA STUDI KASUS KOMUNITAS KRISTEN ROTE DAN SABU KOTA ADMINISTRATIF KUPANG

\section{B. Mata Pencaharian}

Pola persebaran etnik di Kotif Kupang merupakan masalah khas sebagaimana juga dial ami masyarakat perkotaan. Pada umumnya, seperti dikatakan Kiliweri (1984: 111) pembagian pemukiman saat ini masih tetap mempertahankan segi historis dengan para pemukim yang datang tterlebih dahulu. Keadaan ini. dapat dilihat dengan adanya sejumlah kelurahan maupun wilayah kelurahan tertentu merupakan kantong-kantong pemukiman etnik tertentu. Khusus di Kelurahan Kuanino, fenomena demikian cukup jeals. Wilayah-wilayah yang ada dalam kelurahan yang kemudian dalam RW-RW menunjukkan adanya konsentrasi tertentu kelompok etnis pada setiap wilayah pemukiman pada RW I adalah Timor, RW II Rote, RW IV Sabu, RW V rote, RW VI Rote, RW VII campuran, RW VIII Rote, RX IX Rote, dan RW X campuran. Hal serupajuga terjadi di Oetete, tetapi juga tidak begitu tajam pemilihan wilayah pemukiman dalam basis-basis etnik tertentu, karena penyebaran etnik Rote di wilayah ini cukup mmerata di semua wilayah Oetete. Namun demikian, ada dua RW yang menjadi pusat konsentrasi orang Rote, yakni RW II da RW IV. Hampir semua Kepala Keluarga yang menetap di dua RW ini, adalah orang rote, bahkan ada diantaranya yang terikat hubungan kekerabatan.

Nunhila dan Nun Baun Sabu merupakan daerah pemukiman orang Sabu. Sekitar 90 persen dari populalsi penduduk dua kelurahan. Keterogenitas penduduk tanpak juga pada keragaman mata pencaharian. Dari Monografi Kota Administratif Kupang, tahun 1995 disebutkan angkaangka penduduk menurut mata pencaharian sesuai kondisi tahun 1994. Kuanino merupakan kantong konsentrasi pegawai negeri dan pelajar. Angka-angka menunjukkan diantara sebelas ribu penduduk 4.552 orang adalah pegawai negeri sipil, dan 6429 pelajar. Mata pencaharian lainnya seperti; nelayan, buruh, dagang dan tukang juga ada tetapi perbandingannya relatif minim, dibanding yang bekerja ebagai pegawai negeri.

Di Oetete, sekitar 1.185 tenaga kerja, trdistribusi pada PNS/ABRI 863 orang, pedagang/wiraswasta 119 , buruh karyawan 128 dan petani 75 orang. Dibanding dengan totalitas penduduk di Oeete, warga yang metmliki mata pencaharian tetap tergolong rendah $(14,69 \%)$. Bila dikaitkan dengan jumlah penduduk kesluruhan maka terlihat, setiap penduduk yang bekerja menanggung rata-rata 7 orang. Di Kelurahan Naun Baun Sabu, tenaga kerja tetap, juga terhitung rendah, meski dibanding, populasi umum, menunjukkan angka-angka demogarafi di wilayah itu memang tergolong paling rendah dibanding dari semua kelurahan di wilayah Kotif Kupang.

Jumlah tenaga kerja yang tercatat dalam Kelurahan, hanya 473 orang, dari jumlah penduduk 1876. Distribusi penduduk berdasarkan mata pencaharian dapat diliaht, bahwa jumlah buruh bangunan lebih banyak dibanding jenis mata pencaharian lainnya. Buruh bangunan 165 orang, nelayan 150 orang, pegawai negeri sipil 106 orang, wiraswasta 24, ABRI 2 orang dan lain-lain 26 orang.

Dominannya penduduk yang bekerja sebagai buruh bangunan, dan nelayan juga terkait dengan keterampilan yang dimiliki. Dengan modal pendidikan relatif rendah, satu-satunya mata pencaharian yang mudah ditekuni adalah buruh banguna, dan nelayan; adalah keharusan bagi masyarakat Nun Baun Sabu yang tidak memiliki keterampilan lain, mengingat wilayah ini memang berada di pesisir pantai Laut Sawu. 


\section{ORIENTASI KEAGAMAAN MASYARAKATA STUDI KASUS KOMUNITAS KRISTEN ROTE DAN SABU KOTA ADMINISTRATIF KUPANG}

Kondisi tenaga kerja yang relatif rendah di lingkungan etnik Sabu sebagaimana dapat dilihat pada masyarakat Nun Baun Sabu juga nampak di Kelurahan Nunhila. Di Nunhila, distribusi mata pencaharian, terdiri dari, Pegawai Negeri Sipil 86 orang,.ABRI 5 orang, wiraswasta 21 orang. Buruh harian 13 orang, dan lain-lain 7 orang, yang menarik karena data monografi di Kelurahan Nunhila, hanya mencantumkan 6 orang penduduk kelurahan yang memilih bekerja sebagai nelayan, padahal seperti halnya Kelurahan Nun Baun Sabu, kedua pusat pemukiman Sabu yang dominan ini secara geografi berada di bibir pantai Laut Sawu.

Keragaman mata pencaharian penduduk, baik langsung maupun tidak langsung berkaitan erat dengan latar belakang pendidikan. Keahlian tertentu merupakan prasyarat bagi pekerjaan tertentu pula. Dan kecenderungan itu akan semakin trasnparan dimasa datang. Di kelurahan sampel, keterkaitan keberadaan penduduk dengan tingkat pendidikan hampir merupakan keniscayaan.

\section{Kehidupan Keagamaan}

Pada dasarnya, semua responden (Rote dan Sabu), termasuk penganut Protestan yang taat. Fenomena menarik dari sudut pemelukan agama ini, juga nampak dalam pengelompokkan etnik. Ada kecenderungan setiap kelompok etnik tertentu, mempunyai agama tertentu pula. Menurut Liliweri (Liliweri, 1994 : 103) warga yang beragama Protestan umumnya orang Rote, Sabu dan sebagian orang Timor (khususnya yang berasal dari Kabupaten Timor Tengah Selatan) dan sebagian orang Sumba. Warga yang beragama Katholik umumnya orang Flores dan orang Timor (khususnya dari Kabupaten Timor Tengah Utara dan Belu). Sedang penganut Agama Islam adalah warga yang berasal dari Flores (Khususnya Kabupaten Flores Timor) dan penduduk yang berasal dari etnik di luar Nusa Tenggara Timur, misalnya Hindu berasal dari Pulau Bali, sedangkan yang beragama Budha juga berasal dari Bali dan Jawa.

Kemajemukan masyarakat sampel bahkan termasuk penduduk Kotif Kupang adalah konsekuensi logis dari keragaman etnis. Dalam kondisi seperti itu, sebagaimana disebutkan Liliweri (1994 : 106) setiap warga tetap mempertahankan dan mengembangkan nilai-nilai budaya dasarnya mesikipun mereka tetap menjadi warga kota. Hal ini mengakibatkan terjadinya paguyuban-paguyuban yang didasarkan pada etnik atau sub-etnik asal yang bertujuan mempertahankan nilai-nilai adat istiadat serta memperkuat persaudaraan diantara mereka. Liliweri memberi contoh, di Kupang terdapat kerukunan masyarakat Sumba, Batak, Sulawesi Selatan, Flores Timur. Namun yang paling menonjol adalah Ikatan Pelajar dan Mahasiswa, misalnya Ikatan Pelajar Mahasiswa Sumba, Timor Tengah Utara, Belu, Flores Timur, dan Bima. Malahan masih terbentuk beragam paguyuban atau ikatan kekeluargaan itu berdasarkan sub etnik dan klen tertentu. Melalui ikatan kekeluargaan itu dipelihara unsur-unsur adat istiadat, misalnya seni tari dan lagu rakyat di Kuanino dan Nun Baun Sabu. di Kuanino, sub etnik Thi (bagian dari etnik Rote) saja membentuk dua paguyuban kewargaan dengan berbagai aktivis, seperti kebaktian dari rumah ke rumah, arisan dan saling membantu di dalam mengatasi kebutuhan warga etnik. ,

Salah satu ciri menonjol dalam hubungan antar relasi sosial di Nusa Tenggara Timur sebagaimana dapat diamati di daerah sampel adalah tingginya fanatisme etnik. Hal ini bisa .membawa dampalc negatif, karena menurut Liliweri, etnitas 


\section{ORIENTASI KEAGAMAAN MASYARAKATA STUDI KASUS KOMUNITAS KRISTEN ROTE}

DAN SABU KOTA ADMINISTRATE KUPANG

yang sangat tinggi bagi setiap etnik dapat menyebabkan rendahnya kerukunan antar etnik bagi setiap etnik dapat menyebabkan rendahnya kerukunan antar etnik. Akibatnya, sesuai hakekat etnosentrisme, etnik lain selalu dihadapi dengan suasana serba prasangka.

Di samping hubungan persamaan etnik, masyaraka sampel juga direkat oleh ikatan keagamaan. Ikatan keagamaan, dalam hal ini hubungan antar seagama bahkan melampaui batas-batas etnik. Ini dapat dilihat dari seringnya diselenggarakan pertemuan keagamaan, utamanya dalam kebaktian. Paguyuban yang bersifat sosial, misalnya juga didapati di Nunhila dan Nun Baun Sabu, di lingkungan etnik Sabu, khususnya di Nunhila, ada paguyuban keluarga yang disebut IKSAB (Ikatan Kekeluargaan Sabu) lembaga ini, menghimpun orang-orang Sabu yang ada di kelurahan, dan menetapkan iruan anggota setiap bulannya kepada lembaga. Apabila ada kematian maka, lembaga ini akan membantu menyelenggarakan jenazah dan acara kebaktian. Selain itu, masing-masing orang Sabu yang datang "takziyah" memberikan bantuan secara spontan. Konflik antar mereka sangat jarang terjadi, dan kalaupun terjadi terbatas pada masalah warisan atau biaya perkawinan. Pranata Dohawu yang menerapkan semangat kebersamaan dan gotong royong menjadi salah satu unsur tradisi yang masih melekat kuat dalam kehidupan masyarakat Sabu baik di Nunhila maupun di Nun Baun Sabu.

\section{POLA ORIENTASI KEAGAMAAN ETNIS ROTE DAN SAWU}

Secara umum, temuan penelitian di dua kelompok etnis Nusa Tenggara Timur (Rote dan Sawu) apabila dikaitkan dengan teori Lenski tentang orientasi keagamaan, maka pandangan, sikap dan prilaku keagamaan komunitas sasaran khususnya yang berkaitan dengan (1) hubungan dengan Tuhan, (2) hakekat hidttp, (3) hakekat kerja dan waktu, (4) hakekat harta, dan (5) hakekat hubungan dengan alam dapat dikategorikan ke dalam orientasi keagamaan yang bersifat mistisisme, ortodoksi, etikalisme, dan seremonialisme.

Temuan penelitian di dua kelompok etnis (rote dan Sawu) memperlihatkan ada kecenderungan kedua etnis mempunyai sikap yang sarna, ketika menjawab pertanyaan yang berkaitan dengan orientasi tersebut, tetapi dipihal lain terdapat perbedaan fokus, antara Rote dan Sawu, dimana kedunya fflenampakkan sikap kecenderungan yang berbeda. Agar lebih jelas, maka analisis tentang pola orientasi berikut itti, settgaja dipisahkan antara etnis Rote, dan etnis Sawu.

\section{A. Etnis Rote}

\section{Mistisisme}

Orientasi keagamaan yang bersifat mistisisme, menurut Lenski adalah paham keagamaan yang menekankan pentingnya olah batin dalam mencapai Tuhan dan pencarian spiritual atas kebenaran dan hikmah tersembunyi.

Paham, sikap dan prilaku yang mengarah kepada orientasi mistisisme pada pola keberagamaan orang Rota dapat dilihat pada aspek hubungan dengan Tuhan, khususnya yang berkai, tan dnegan paham mereka tentang makna beribadah. Kecenderungan mistisisme dalam hal ini amat kuat dengan dukungan oleh $80 \%$ responden. Kecenderungan ini juga terjadi berkaitan dengan fungsi waktu kerja, terutama ketika mereka diperhadapkan kepada pertanyaan tentang "apa makna hidup yang sebenarnya", yang dilihatnya sebagai kesempatan mendekatkan diri kepada Tuhan. 
ORDENTASI KEAGAMAAN MASYARAKATA STUDI KASUS KOMUNITAS KRISTEN ROTE DAN SABU KOTA ADMINISTRATE KUPANG

\begin{abstract}
Orientasi yang sama dapat diketahui lewat ekspresi responden mengenai hakekat harta, akah tetapi penilaian harta lebih dari sekedar kuantitasnya. Justeru yang lebih penting adalah bahwa harta tidak perlu banyak, yang penting memiliki berkah. Inheren dengan pengertian berkah disini adalah kualitas atau cara bagaiaman harta itu diperoleh, yang rujukannya dikembangkan kepada sifatsifat jujur, adil dan tidak eksploitatif baik dalam kaitannya dengan manusia maupun dengan lingkungan.
\end{abstract}

\section{Ortodoksi}

Orientasi bersifat ortodoksi, menurut Lenski adalah suatu pola keberagamaan yang menekankan pentingnya pelaskanaan ajar an agama secara mumi dan konsekuen sesuai petunjuk kitab suci (skripptualistik).

Kecenderungan orientasi ortodoksi pada aspek hubungan dengan Tuhan, khususnya mengenai tujuan beribadah, bahwa beribadah dengan soal hubungan dengan Tuhan, kecenderungan ortodoksi juga dapat diketahui dari pernyataan mereka mengenai cara pendekatan diri kepada Tuhan. Umumnya responden menyatakan mendekatkan diri kepada Tuhan dengan cara beribadah dan melaksanakan soal-soal sosial. Ortodoksi amat kuat ekresinya dalam kaitan dengan hakikat hidup. Ajaran agama yang menganut pola keseimbangan antara kebahagiaan dunia dan akhirat, sebagai tujuan hidup ditanggapi secara proporsional oleh responden. Demikian juga pandangan mengenai kedudukan manusia di dunai sebagai pengelola dunia (khalifah dalam teks Islam) menunjukkan adanya kesadaran ortodoksi. Meski tidak dominan orientasi ortodoksi juga terlihat ketiak mereka diperhadapkan kepada preferensi perujukan mengenai pemecahan masalah keagamaan tertentu. Dalam hal ini responden memiliki kecenderungan kuat bahwa sering terjadinya masalah keagamaan seharusnya selalu diupayakan penyelesaiannya melalui proses-proses rasional dengan melakukan elaborasi masalah tersebut melalui orang-orang atau pihak-pihak yang berkompeten. Demikian juga memberikah prioritas pada ibadah (guna mencapai kebahagiaan di dunia dan akhirat) sebagai prioritas dari berbagai kegiatan hidup lainnya mengindikasikan orientasi ortodoksi yang jelas.

Ortodoksi bahkan memiliki refleksi lebih jauh pada orientasi nilai budaya yang lain, seperti misalnya, aspekaspek yang berkaitan dengan hakekat harta kekayaan. Elaborasi dari tema harta dan penelitian ini diindikasikan antara lain lewat cara seseorang mencapai tujuan hidup. Ternyata responden menempatkan kerja keras sebagai sesuatu yang bersifat condismo sini quanon dalam rangka mencapai kebahagiaan hidup dunia dan akhirat. Hal ini bersumber dari pemahaman ajaran agama Kristen tentang kerja, bahwa bekerja sesungguhnya adalah merupakan fungsi (wujud) dart ibadah (pengabdian) kepada Tuhan.

Berkenaan dengan aspek hubungan manusia dengan alam, kecenderungan ortodoksi juga tampak pada pemahaman mengenai arti alam bagi manusia, yang menurut orang Rote, tidak lain sebagai amanah Tuhan yang harus dimanfaatkan dan dipelihara, selain itu prilaku kesehatan masyarakat juga memperlihatkan kecenderungan orientasi yang sama, dengan kuatnya orientasi medis (medical oriented) bagi responden. 


\section{ORIENTASI KEAGAMAAN MASYARAKATA STUDI KASUS KOMUNITAS KRISTEN ROTE DAN SABU KOTA ADMINISTRATE KUPANG}

\section{Etikalisme}

Dari kategorisasi Lenski, diketahui bahwa etikalisme diidentifikasikan sebagai suatu orientasi keagamaan yagn menekankan pentingya upaya pemeluk agama untuk memajukan kesejahteraan umat manusia. Kebenaran agama diukur dari sumbangsih seseorang kepada pembangunan nilai-nilai moral dan kepantasan umat manusia. Substansi agama, dengan demikian, lebih penting dibanding kulitnya.

Kecenderungan etikalisme orang Rote dapat dilihat melalui penyataan mengenai hakekat hidup, khususnya dalam memandang kedudukan manusia di bumi. Mengenai hal ini, responden lebih cenderung melihat manusia sebagai makhluk yang bertugas mewujudkan kesejahteraan bagi manusia dan alam sekitar. Hal ini memiliki kesepadanan dengan pandang mengenai hakekat kerja, terutama berkaitan dengan tujuan yang dilihatnya sebagai upaya untuk menciptakan kesejahteraan hidup manusia, lebih dari tujuan-tujuan individual seperti untuk mendapatkan keridhoan Tuhan, memperoleh rezeki atau untuk mencari keselamatan.

Orientasi etikalisme lainnya terjadi aspek hubungan alam dan lingkungan. Etika dan kearifan lingkungan masyarakat yang memang secara umum terjadi pada masyarakat sederhana, ternyata masih cenderung memiliki resistensi terhadap eksploitasi alam dan lingkungan. Kerusakan dan bencana alam, oleh orang Rote dianggap sebagai satu refleksi dari kerusakan dan terganggunya keseimbangan alam dan lingkungan itu sendiri yang tentu saja diakibatkan oleh prilaku manusia.

\section{Seremonialisme}

Menurut Lenski, seremonialisme diidentifikasi sebagai orientasi keagamaan yang memandang bahwa upacara/ritus-ritus itu merupakan inti ajaran agama, yang dipentingkan adalah penyelenggaraan upacara dan tidak terlalu menghiraukan substansi dari upacara itu sendiri. Keberagamaan seseorang, karena itu diukur dari aktivitas keupacaraannya.

Satu diantara indikasi orientasi seremonialisme bagi masyarakat lokal adalah pandangan mengenai tujuan beragama yang lebih ditujukan kepada orientasi keselamatan, lebih dari orientasi cinta kepada Tuhan, mengikuti aturan Tuhan dalam kitab suci atau berbuat baik kepada sesama manusia. Orientasi itu juga dilihat cenderung masih kuat melalui sudut jaringajaringan dan struktur sosial. Peran tokoh-tokoh informal seperti tokohtokoh agama dan adat serta nilai-nilai tradisi masih cukup kuat dikalangan masyarakat Rote yang tinggal di perkotaan. Hal inii terbukti dari preferensi umat Kristiani untuk mengembalikan pemecahan masalah keagamaan kepada tokoh-tokoh dan tradisi cukup dominan ketimbang mereka yang menempuh jalur formal.

\section{B. Etnis Sabu}

\section{Mistisisme}

Responden masyarakat Sabu, terhadap masalah-masalah keagamaan, pada beberapa aspek masih cenderung berorientasi mistisisme. Kecenderungan ini tampak menguat di dua lokasi penelitian, yaitu Kelurahan Nunhila, dan Kelurahan Nun Baun Sabu. Meskipun, aspek mistik ini mendominasi penilaian masyarakat, terhadap 


\section{ORIENTASI KEAGAMAAN MASYARAKATA STUDI KASUS KOMUNITAS KRISTEN ROTE DAN SABU KOTA ADMINISTRATE KUPANG}

munculnya kecenderungan tertentu, diantara dua lokasi penelitian, terdapat adanya persamaan sikap.

Hal ini dapat dilihat, pada pernyataan tentang arti atau makna ibadah. Penilaian reponden, bahwa masalah ibadah adalah masalah yang berkaitan langsung antara manusia sebagai makhluk dan Tuhan sebagai Khalik (pencipta). Hubungan vertikal itu juga berarti bahwa proses akhir, atau finalitas dari semua peranggungjawaban manusia terhadap Tuhan, adalah merupakan tanggung jawab manusia itu sendiri.

Intervensi lain terhadap hubungan vertikal ini, dianggap sebagai "penyimpangan", yang bukan saja bisa termasuk tatanan hubungan hamba dengan Tuhan, tetapi juga mempengaruhi kesadaran moral atau semangat keagamaan, dalam keaitannya dengan pengabdian dan peyembahan kepada Tuhan. Mengatnya mistisisme, berkaitan masalah arti dan makna ibadah ini dibuktikan pilihan responden di Nunhila, $62 \%$, dan Nun Baun Sabu $64 \%$ dari totalitas responden.

Kecenderungan terhadap mistisisme, juga tampak pada pernyataan reponden tentang tujuan hidup di dunia. Mayoritas responden (baik di Nunhila maupun Di Nun baun Sabu) mempunyai keinginan kuat untuk memanfaatkan umur dan kesempatan hidup di atas dunia, sebagai peluang untuk mengintensifkan hubungan dengan Tuhan. Pernyataan ini menunjukkan adanya keyakinan yang masih cukup kuat terhadap peran agama sebagai motivator dan dinamisator dalam kehidupan sehari-hari. Meski, kehadiran responden di daerah penelitian, merupakan pendatang, yang sejak awal dikampung asal (Pulau Sabu), mereka telah memiliki sikap dan pandangan. yang mapan terhadap masalah keagamaan, namun di daerah pemukiman baru, sikap itu tetap tidak berubah. Ada keinginan untuk mempertahankan pernyataan tersebut, dengan jalan memperkuat hubungan sosial, dan mengintensifkan hubungan solidaritas sosial dengan motifasi dan semangat keagamaan.

Secara umum, pada hal-hal yang berkaitan dengan pelaksanaan ibadah, respoden memberikan jawaban yang cenderung sangat kuat ke mistisisme. Pandangan ini, juga tampak ada pernyataan tentang kedudukan manusia. Baik di Nunhila, maupun di Nun Baun Sabu, responden menilai kedudukan manusia dalam konteks hubungan dengan Tuhan. Pandangan ini bahkan semakin kuat, dengan pernyataan bahwa, bagi manusia sebagai makhluk Tuhan tidak ada alternatif lain atau kedudukan lain manusia di atas dunia ini kecuali menjalankan fungsinya sebagai "hamba" dengan segala konsekuensinya.

Penilaian responden tentang harta, juga menunjukkan orientasi mistik yang kuat. Seperti halnya, pada semangat orang Rote tentang harta, orang Sabu juga mementingkan (sebagai prioritas utama) harta benda secara kuantitatif, akan tetapi bagaimana harta menjadi "sarana" yang efektif bagi manusia, untuk menjalankan fungsi "kehambaan" di dunia ini.

Konsekuensi dari peniulaian harta kenyataan secara mistik, reponden lebih bersikap selektif dalam mengumpulan harta kekayaan. Beberapa responden merujuk pada istilah lokal tentang "uangpanas", yaitu uang yang diperoleh secara ilegal (menurut ketentuan hukum agama). Uang atau harta seperti itu, meki jumlahnya banyak tidak akan dapat memberikan 


\section{ORIENTASI KEAGAMAAN MASYARAKATA STUDI KASUS KOMUNITAS KRISTEN ROTE DAN SABU KOTA ADMINISTRATE KUPANG}

ketenan gan bagi pemiliknya. Hal ini diseabkan tidak ada "berkah", legitimasi Ilahy terhadap harta benda yang dikumpulkan atau diperoleh.

\section{Ortodoksi}

Semangat ortodoksi, tampak pada pernyataan responden tentang tujuan beragama. Masyarakat Sabu, harus dilakukan secara konsekuen berdasarkan aturan-aturan yang telah dibakukan dalam kitab suci. Kecenderungan konteksualisasi ini, dominan di dua daerah penelitian yang didiami mayoritas masyarakat Sabu. Mereka bahkan secara ektrim menolka adanya intervensi atau campur tangan terhadap doktrin-doktrin keagamaan, yang harus dilakukan.

Kecederungan ini, juga terlihat ketika responden memberikan jawaban tentang cara yang digunakan ntik mencapai tujuan. Ada beberapa alasan yang dikemukakan, mengapa kecenderungan ortodoksi terus mendominasi pernyataan responden pada aspek yang berkaitan dengan agama dalam hubungannya dengan kehidupan sosial. Pendapat ortodoksi bago orang Sabu, dianggap relevan dengan adanya kecenderungan masyarakat yang mulai terpengaruh oleh adanya perubahanperubahan yang terjadi dalam kehidupan sosial mereka. meskipun (seperti lelah dikemukakan) disati pihak masyarakat lokal berusaha mempertahankan nilai-nilai yang bersifat tektual, berdasarkan pesan-pesan dari kitab suci, akan tetapi pihak lain, mereka tidak bisa mengingkari kenyataan dengan perubahan pesat yang terjadi di sekitarnya. Oleh karena itu, ibadah bukanlah semata-mata menampakkan hasil dalam mengentalkan emosi keagamaan masyarakat, tetapi juga bisa membias pada semakin mapannya kehidupan sosial. resiko dari sikap ini, adalah beribadah menurut orang Kristen Sabu, selain bernilai ukhrawi, juga harus mempunyai pengaruh positif, merekat integrasi sosial dan harmoni didalam hidup. Semangat ortodoksi, semakin tajam, dalam pilihan responden tentang cara mendekatkan diri kepada Tuhan.

Beribadah, bagi masyarakat sabu, selain harus mengikuti aturan-aturan yang telah baku (kebaktian di gereja, berdo'a). Amal Sholeha, adalah suatu konsep keagamaan, yang menurut pcngamatan orang Sabu, adalah suatu keseimbangan antara pelaksanaan ibadah formal dengan kemampuan seseorang (umat beragama) memberikan kontribusi positif dalam kehidupan kolektifnya.

Pada kegiatan keagamaan yang dianggap penting, kecenderungan ortodoksi juga dominan. Ada 72 persen responden di dua lokasi penelitian memperkuat kecenderungan tersebut. Beribadah, bagi orang Sabu, selalu dilihat dalam kapasitas keterkaitan antara tujuan finalnya (ukhrawi) dengan tujuan awalnya (duniawi). Ibadah, atau melaksanakan kegiatan keagamaan, bagi responden termasuk masalah yang penting dilakukan secara terprogram dan berkesinambungan. Namun demikian, makna ibadah atau pengaruh dari kegiatan keagamaan yang dilakukan seseorang Kristen Sabu, implikasinya harus dapat diaktualisasikan dalam kehidupan di dunia. Itu sebabnya, bagi responden, mengisi waktu dengan melakukan kegiatan keagamaan, harus dapat memberikan keuntungan ganda, yakni dunia dan akhirat sekaligus.

Demikian juga cara mencapai tujuan hidup, harus dilakukan berdasarkan prinsip-prinsip yang bersifat ortodoksi. Secara mendasar, pandangan 


\section{ORIENTASI KEAGAMAAN MASYARAKATA STUDIKASUS KOMUNITAS KRISTEN ROTE}

DAN SABU KOTA ADMINISTRATIF KUPANG

ortodoksi ini menempatkan tujuan hidup sebagai rengkaian usaha mencapai kebahagiaan, sedang jalan untuk mencapai hams dengan berkerja keras. Pandangan yang sama, juga menonjol tentang tujuan bekerja. Kecenderugan ortodoksi, seperti yang tampak dalam beberapa pernyataan responden, disebabkan oleh karena mereka selalu mengkaitkan usaha dunianya, dengan tujuan-tujuan keagamaan sebagai tujuan akhir dari hidup manusia. Hidup adalah pemberian Tuhan, dan hasil pekerjaan adalah rezeki yang tidak bisa dipahami semata-mata dari aspek lahiriah. Rezeki tidak bisa diperkirakan. Karena kualitas dan kuantitasnya, juga tergantung pada keridhoan Tuhan. Relevan dengan sikap tersebut di atas, responden berpendapat, idealnya seorang Kristen yang baik, hams lebih banyak memberikan sumbangannya untuk kepentingan fakir miskin dan anak yatim piatu.

Yang menarik, karena responden lebih tertarik menyerahkan bantuan (sumbangan), sedekahnya kepada lembaga panti asuhan, dan anak yatim piatu, dan kepada pemuka agama.

\section{Etikalisme}

Persebaran dalam pilihan, dimana pendapat responden direkam, hampir tidak ada kecenderungan etikalisme yang menonjol. Kecuali, pernyataan responden di Nun Baun Sabu, justru terdapat 34 reponden menilai tujuan beragama secara etikalisme. Ini berarti, sekitar 60 persen berpendapat bahwa, dalam beragama manusia dituntut agar dapat merefleksikan ketaatannya terhadap agama, dalam pergaulan sosialnya.

, Pernyataan ini, tampaknya dipengaruhi oleh berbagai faktor, termasuk pengaruh kondisi geografis dan letak pemukiman masyarakat yang berbeda di tengah kota propinsi yang sedang berkembang pesat. Kontak antara berbagai etnis dan penduduk lain dengan variasi budaya dan latar belakang profesi, asal daerah, pendidikan dan sebagainya, mendorong responden lebih bersifat prakmatis yang memperhitungkan hubungan sosialnya dengan lingkungan dan jaringan dimana mereka beradaptasi. Di Kupang,dengan tingkat modernisasi pembangunan relatif tinggi, serta mobilitas sosial yang semakin dinamis, masalah etikalisme ini tampaknya merupakan suatu keharusan.

Sikap responden pada berbagai permasalahan, khususnya etikalisme tidak menonjol, dan seperti telah dikemukakan rata-rata didominasi kecenderungan lain.

\section{Seremonialisme}

Persebaran responden, baik di Nunhila maupun di Nun Baun Sabu, kecenderungan seremonialisme, tidak pernah menunjukkan angka yang tinggi.

Namun demikian, meski tidak cukup dominan, frekuensi pendapat yang relatif tinggi, mengacu pada seremonialisme, dapat dilihat pada pernyataan tentang penggunaan waktu luang. Pada pilihan-pilihan yang khusus mendeskripsikan tentang penggunaan waktu luang, justru seremonialisme menempati peringkat kedua sesudah mistisisme.

Menguatnya seremonialisme disini, dapat dipahami, bila dikaitkan dengan pemahaman masyarakat Sabu tentang waktu. Waktu selain dianggap sebagai sesuatu yang "abstrak" dengan mengandung unsur-unsur yang lebih bersifat rahasia. Oleh karena itu, waktu 


\section{ORIENTASI KEAGAMAAN MASYARAKATA STUDI KASUS KOMUNITAS KRISTEN ROTE DAN SABU KOTA ADMINISTRATE KUPANG}

cenderung dipahami sebagai "misteri" yang belum diungkap secara total. Masyarakat Sabu, secara minimal, merasa memiliki keharusan untuk memahami fungsi waktu, sepanjang yang bisa diungkap, sehingga mereka dapat membangun kearifan dalam dirinya, dan sekaligus mampu mengantisipasi tanda-tanda musim. dari pemahaman ini, mereka susun penentuan hari baik dan tidak baik.

Bertolak dari situ, orang Sabu perlu mengetahui perputaran waktu karena hal ini berkaitan dengan musim bercocok tanam, menyadap nira, dan juga memulai pekerjaan. Hal tersebut, semuanya perlu dilakukan dengan mengadakan upacara keagamaan.

\section{ORINTASI DAN KAITANNYA DENGAN SETTING BUDAYA}

Deskripsi tentang hasil temuan peneliti, sebagaimana dikemukakan secara singkat pada bagian terdahulu, hanya dapat dipahami lebih jelas, manakala kecenderungan tersebut, dan relevansinya dikaitkan dengan setting budaya lokal, dalam hal ini budaya Rote dan Sabu.

Kendatipun, ada perbedaan fokus dan arah kecenderungan pada berbagai hasil temuan, namun pada prinsipnya dapat dikemukakan wahwa kedua etnis sasaran, yakni Rote dan Sabu, relatif memiliki persamaan dalam perwujudan kecederungan orientasi keagamaan.

Seperti saja, adanya, kecenderungan umum pada ortodoksi, dalam pola keberagamaan masyarakat NTT. Kecenderungan tesebut terungkap dalam manifestasi kehidupan yang berkaitan dalam lima orientasi nilai budaya dengan Tuhan, hakekat hidup, hakekat kerja, waktu dan hubungan dengan alam.

Kecenderungan ortodoksi tersebut jika dielaborasi lebih jauh bermakna bahwa orang NTT (Rote dan Sabu), setidaknya pada lokasi penelitian adalah merupakan penganut Kristen (Protestan) yang ralatif taat beragama, memiliki komitmen otodoksi, menurut Taufiq Abdullah, dengan berdasarkan bahasannya pada ortodoksi Islam adalah penganut ajaran yang utuh dan murni, menekankan pentingnya kesesuaian antara tindakan dan syariat. Apabila kelompok ini muncul dalam sebuah gerakan keagamaan, maka gerakannya akan mengambil berbagai bentuk misalnya, melalui gerakan pemurnian tarekat, ataupun menghancurkan segala macam tingkah laku agama yang dianggap bid'ah (Taufiq Abdullah, 1974 : 5).

Jika, ortodoksi merupakan tipe ideal dari proses keberagamaan sebuah komunitas agama, maka sesungguhnya akan terjadi berlapis-lapis kenyataan keberagamaan pada suatu komunitas agama. Sebab menurut Taufiq Abdullah, "ketika suatu penganut mulai menyesuaikan hidup mereka berdasarkan simbol-simbol agama yang dianjurkan (ortodoksi), penganut lain masih terikat patokan lama, dan yang lain menyesuaikan diri dengan tuntutan-tuntutan baru". Maka terjadilah berlapis-lapis perkembangan; seakan-akan dalam suatu ketika, masyarakat penganut berada dalam beberapa lapis sejarah.

Dalam konteks komunitas agama pada kasus Rote dan Sabu, dapat dipahami bahwa selain anggota penganut Kristen yang sudah sampai pada taraf keberagamaan yang ortodoksi, dalam temuan ini merupakan kelompok mayoritas, masih terdapat lapis lain, yang masih tetap berkutat pada orientasi mistisisme, dan juga sebagian kecil berorientasi etikalisme dan seremonialisme.

Menurut hemat kami, jalan menuju pola hidup ortodoksi paling tidak disebabkan dua faktor. Faktor pertama adalah lamanya masyarakat bersangkutan melakukan kontak dan pergumulan dengan agama yang dianutnya. Faktor kedua, adalah intensitas sosialisme dan internalisasi ajaran agama yang dianut tersebut melalui berbagai saluran transmisi. 


\section{ORffiNTASI KEAGAMAAN MASYARAKATA STUDI KASUS KOMUNITAS KRISTEN ROTE DAN SABU KOTA ADMINISTRATIF KUPANG}

Rentang kontak orang Rote dan Sabu dengan agama Kristen (Protestan) sudah melalui sejarah yang amat panjang. Kontak Rote dan Belanda secara real terjadi tahun 1653, setelah menggeser kedudukan Portugis di pulau Rote. Demikian pula kontak Belanda dengan Sabu, juga sudah berlangsung cukup lama. Pembentukan pemukiman awal orang Sabu di Wilayah Administratif Kotif Kupang sekarang, berlangsung sejak tahun 1810, ketika Resident JA Hazaart, membentuk daerah penyangga di beberapa daerah Kupang. Untuk kepentingan itu, Belanda mendatangkan penduduk dari Solor, Sabu, dan Rote ke pulau Timur (Pemda Kotif Kupang, 1995 : vi). Keberadaan Belanda di wilayah pemukiman Rote dan Sabu, selain membawa misi ekonomi juga misi agama. Pengaruh misi tersebut berlangsung terus sampai Rote dan Sabu dikenal sebagai sal ah satu basis Kristen Protestan di NTT. Intensitas sosialisasi dan internalisasi ajar an agama Kristen bagi masyarakat Rote dan Sabu, merupakan konseuensi logis dari faktor pertama tadi. Jalur utama dalam hal ini adalah melaui jalur pendidikan dan gereja. Bahkan, ada kecenderungan perkembangan pendidikan dikedua kelompok etnis ini, juga berkaitan dengan peyebaran agama.

Dibanding dengan etnis Sabu, perkembangan komunitas Rote di Kupang jauh lebih pesat, dalam arti mereka mendapatkan kemudahan-kemudahan untuk memapankan pranata sosial pada lingkungan sosial yang baru. Menurut Mubyarto, kemudahan konsentrasi agama Kristen di Rote, karena dua hal. Pertama, secara kultur, Rote sebenarnya telah terpecah kedalam sedikitnya 20 sub kultur nusak. Masing-masing sub kultur berusah'a menampilakan identitas dirinya dengan cara saling meyerang antar sub kultur. Karena itu orang Rote membutuhkan unsur perekat dalam bentuk agama. Kedua, letak Pulau Rote, tidak terlalu jauh dari pulau Timor.

Orientasi ortodoksi, pada komunitas agama Kristend Rote dan Sabu, menurut hemat kami, selain dua faktor tersebut di atas (pergumulan panjang dengan agamanya dalam sejarah, dan pola sosialisasi yang mantap dan sistematis) juga karena faktor sosialitas yang bersumber dari faktor keterdidikan dan warisan budaya, yang dalam banyak hal dipengaruhi sistem rekayasa sosial pemerintah Belanda. Bahwa masih terdapat, etikalisme, seremonialisme, dan mistisisme, yang kadangkala lebih dominan, menunjukkan tidak terlepas dari adanya segmen pemeluk agama Kristen Protestan yang masih tetap memiliki kaitan kuat dengan budaya lokal aslinya, dan pengaruh lingkungan sosial dan kontak sejarah dengan berbagai kelompok lain.

Hal ini adalah merupakan sebuah proses normal, dari sebuah fenomena pertemuan dua nilai budaya dan agama. Selalu terjadi mekanisme tawar menawar antara nilai baru yang dibawakan oieh agama, dan nilai lama yang telah lama bersemi sepanjang sejarah lokal masyarakat bersangkutan. Fenomena tersebut menurut Harry J. Benda (Dalam Taufiq Abdullah, 1974 : 33) disebut gejala kontinuitas dan perubahari. Menurut Grunbaum (1983 : 21) disebutnya sebagai suatu masalah hubungan antara lapisan peradaban universal yang berkoeksistensi dengan peradaban kedaerahan atau rangkaian saling reaksi antara tradisi-tradisi besar dan kecil. 
ORIENTASI KEAGAMAAN MASYARAKATA STUDI KASUS KOMUNITAS KRISTEN ROTE DAN SABU KOTA ADMINISTRATE KUPANG

\section{DAFTAR PUSTAKA}

Abdullah, Taufiq, Islam di Indonesia, Jakarta, 1974.

Aloysisus, Liliweri, Prangka Sosial dan Efektifitas Komunikasi Antara etnik.

Grunebaum, Gustave E. Von, Islam, Kesatuan dan Keragaman, Yayasan Pengkhidmatan, Jakarta, 1983.

Mubyarto, dkk. Etos Kerja dan Kohesi Sosial, Aditya Media, Yogyakarta, 1985.
Sekretaris Kantor Walikota Kupang, Monografi Kota Administratif Kupang 1995.

Tim Penyusun Monografi Daerah Nusa Tenggara Timur (Timor, Flore, Rote, Sabu) Proyek Pengembangan Media Kebudayaan Departemen Pendidikan dan Kebudayaan $R l$ (tanpa tahun)

Nico L. Kana, Dunia Orang Sawu, Sinar harapan, Jakarta, 1983. 